\title{
SALINITY VARIATIONS IN SEA ICE
}

\author{
By G. F. N. Cox \\ (Department of Earth Sciences, Dartmouth College, Hanover, New Hampshire 03755, U.S.A.) \\ and W. F. WEEKS \\ (U.S. Army Cold Regions Research and Engineering Laboratory, Hanover, New \\ Hampshire 03755, U.S.A.)
}

\begin{abstract}
The salinity distribution in multi-year sea ice is dependent on the ice topography and cannot be adequately represented by a single average profile. The cores collected from areas beneath surface hummocks generally showed a systematic increase in salinity with depth from $0 \%$ at the surface to about $4 \%$ at the base. The cores collected from areas beneath surface depressions were much more saline and displayed large salinity fluctuations.

Salinity observations from sea ice of varying thicknesses and ages collected at various Arctic and subArctic locations revealed a strong correlation between the average salinity of the ice $\bar{S}$ and the ice thickness $h$. For salinity samples collected from cold sea ice at the end of the growth season, this relationship can be represented by two linear equations: $\bar{S}=14.24-19.39 h(h \leqslant 0.4 \mathrm{~m}) ; \bar{S}=7.88-1.59 h(h>0.4 \mathrm{~m})$. It is suggested that the pronounced break in slope at $0.4 \mathrm{~m}$ is due to a change in the dominant brine drainage mechanism from brine expulsion to gravity drainage. A linear regression for the data collected during the melt season gives $\bar{S}=1.5^{8}+0.18 h$. An annual cyclic variation of the mean salinity exists for multi-year sea ice. The mean salinity reaches a maximum at the end of the growth season and a minimum at the end
\end{abstract} of the melt season.

RÉsumé. Variations de salinité dans la glace de mer. La distribution de la salinité dans la glace de mer vieille de plusieurs années dépend de la topographie de la glace et ne peut être convenablement représentée par un profil moyen unique. Les échantillons recueillis dans des zones retirées sous les buttes de pression (hummocks) de surface ont généralement montré un accroissement systématique de la salinité avec la profondeur de o\% en surface, à environ $4 \%$ à la base. Les échantillons recueillis sous les zones de dépression de la surface étaient beaucoup plus salés et donnaient lieu à de larges fluctıations de la salinité.

Les observations de salinité sur des glaces de mer d'épaisseur et d'âge variables en des emplacements variés, arctiques ou subarctiques, ont révélé une forte corrélation entre la salinité moyenne de la glace $\bar{S}$ et l'épaisseur de la glace $h$. Pour des échantillons recueillis dans une glace marine froide à la fin de la saison de croissance, cette relation peut être représentée par deux équations linéaires: $\bar{S}=14,24-19,39 h(h \leqslant 0,4$ $\mathrm{m}) ; \bar{S}=7,88-\mathrm{r}, 59 h(h>0,4 \mathrm{~m})$. On suggère que la rupture prononcée de la pente de la droite pour $h=0,4 \mathrm{~m}$ est dûe au changement dans le mécanisme prépondérant de drainage de la saumure passant de l'expulsion de la saumure à un drainage par gravité. Une régression linéaire pour les données recueillies durant la saison de fusion donne $\bar{S}=1,58+0,18 h$. Une variation cyclique annuelle de la salinité moyenne existe pour des glaces marines pluriannuelles. La salinité moyenne atteint un maximum à la fin de la saison de croissance et un minimum à la fin de la saison de fusion.

Zusammenfassung. Schwankungen des Salzgehalts im Meereis. Die Salzgehaltsverteilung in mehrjährigem Meereis ist von der Eistopographie abhängig und kann nicht durch ein einfaches Durchschnittsprofil hinlänglich beschrieben werden. Die unter oberflächlichen Buckeln gewonnenen Bohrkerne zeigten generell eine systematische Zunahme des Salzgehalts mit der Tiefe von $0 \%$ an der Oberfläche bis ungefähr $4 \%$ an der Unterseite. Die unter Oberflächendepressionen gewonnenen Bohrkerne waren wesentlich salzhaltiger und zeigten grosse Salzgehaltsschwankungen.

Die Beobachtungen des Salzgehalts im Meereis von verschiedener Dicke und Alter, angestellt an mehreren arktischen und subarktischen Stellen, liessen eine starke Korrelation zwischen dem durchschnittlichen Salzgehalt des Eises $\bar{S}$ und der Eisdicke $h$ erkennen. Für Salzgehaltsproben, die von kaltem Meereis am Ende der Wachstumszeit gesammelt wurden, kann diese Beziehung durch zwei lineare Gleichungen ausgedrückt werden: $\bar{S}=14,24-19,39 h(h \leqslant 0,4 \mathrm{~m}) ; \bar{S}=7,88-1,59 h(h>0,4 \mathrm{~m})$. Es wird vermutet, dass der ausgeprägte Knick in der Neigung bei $0,4 \mathrm{~m}$ dem Wechsel des vorherrschenden Drainagemechanismus von der Austreibung des Salzwassers zu einer Schwerkraftentwässerung zuzuschreiben ist. Eine lineare Regression für die während der Schmelzzeit gesammelten Daten ergibt $S=1,58+0,18 h$. Für mehrjähriges Meereis besteht eine jährliche zyklische Schwankung des mittleren Salzgehalts. Der mittlere Salzgehalt erreicht am Ende der Wachstumszeit ein Maximum und mit Schluss der Schmelzperiode ein Minimum.

\section{INTRODUCTION}

Despite the importance of the salinity profile in determining the mechanical, thermal, and electromagnetic properties of sea ice, few ice salinity data have been collected. Those data which are available have usually been obtained as an adjunct to some other study and have therefore not been systematically analyzed in their own right. 
The salinity distribution in multi-year ice has been particularly neglected. The prime reference on this subject is the study Schwarzacher (1959) performed during the drift of ice station Alpha in the Arctic Ocean. In this study he computed an average multi-year salinity profile based on the salinity profiles from 40 cores. This mean profile is commonly quoted in the literature and has served as a basis for a variety of calculations in which the profile properties of multi-year sea ice are important (Assur, r967; Untersteiner, r967; Weeks and Assur, I967; Maykut and Untersteiner, I971). However, his study does not encompass such variables as surface topography, internal structure, age, and thickness, all of which must affect the multi-year salinity profile; nor does it adequately describe the transition from a first-year to a multi-year ice salinity profile and the brine drainage mechanisms (Untersteiner, 1967).

The present study was undertaken to supplement Schwarzacher's data and to determine the variation, if any, in multi-year ice salinity profiles with changes in ice surface topography. The results also led to an examination of the variation of the mean salinity of both first-year and multi-year ice with changes in ice thickness.

\section{Field SITES AND PROGEDURES}

Most of the multi-year ice salinity data used in this paper were collected during March and April 1972 from an area near the main AIDJEX (Arctic Ice Dynamics Joint Experiment) camp, located in the Beaufort Sea at approximately lat. $75^{\circ} \mathrm{N}$., long. $148^{\circ} \mathrm{W}$. The sampling area is shown in Figure I. Here salinity cores were collected from beneath both melt hummocks and the adjacent depressions which presumably represent sites at which melt ponds were located during the summers. Care was taken to avoid pressure ridges and areas of deformed ice. Salinity samples from new ice were collected at daily intervals from a $3 \mathrm{~m} \times 3 \mathrm{~m}$ test pond cut in the thin ice of a refrozen lead. Continuous ice samples $7.6 \mathrm{~cm}$ in diameter

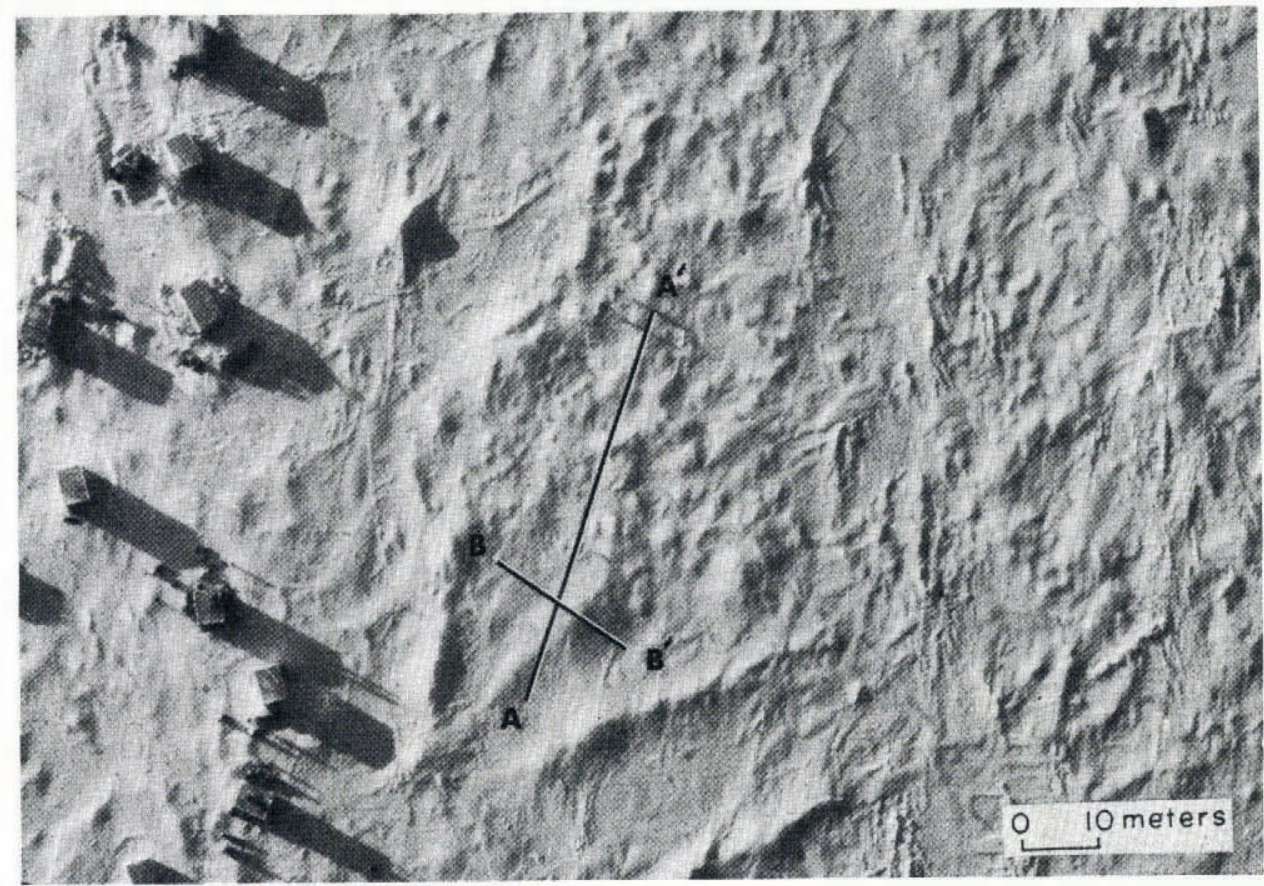

Fig. I. Sampling area near main AID JEX camp. $A-A^{\prime}$ and $B-B^{\prime}$ are cross-section lines (approximate). 
were obtained with a CRREL corer attached to a power drill. Once the core was removed from the ice, it was quickly cut into $10 \mathrm{~cm}$ sections with a band saw $(2 \mathrm{~cm}$ sections for very thin ice) and sealed in airtight one-quart (c. one liter) freezer containers. The salinity of the melted ice was then determined to $\pm 0.1 \%$ with a Beckman conductivity bridge. Because of cold air $\left(-25^{\circ} \mathrm{C}\right)$ and low ice temperatures during sampling, there was very little brine drainage. No large brine pockets and only a few brine drainage tubes were observed, so that the salinity profiles should be representative. Approximate ice temperatures were obtained for some cores as soon as they were removed from the ice sheet by inserting a thermistor into the core center.

These results were combined with additional salinity observations collected by investigators on field projects on the Labrador coast, the Bering and Beaufort Seas, and Viscount Melville Sound. The sampling techniques were similar to those used in this study, except that salinities in the Hopedale, Labrador, study were determined by hydrometer.

\section{RESULTS}

Salinity profiles of the melt hummocks differed significantly from those of the depressions. The hummocks showed a systematic increase in salinity with depth from $0 \%$ at the surface to about $4 \%$ at the base (Fig. 2); the depressions showed large, irregular salinity fluctuations (Figs. 3 and 4 ), and the upper layers in these cores showed salinity values up to $6.3 \%$. Because of the low ambient temperatures, it was impossible to avoid cooling of the core upon removal

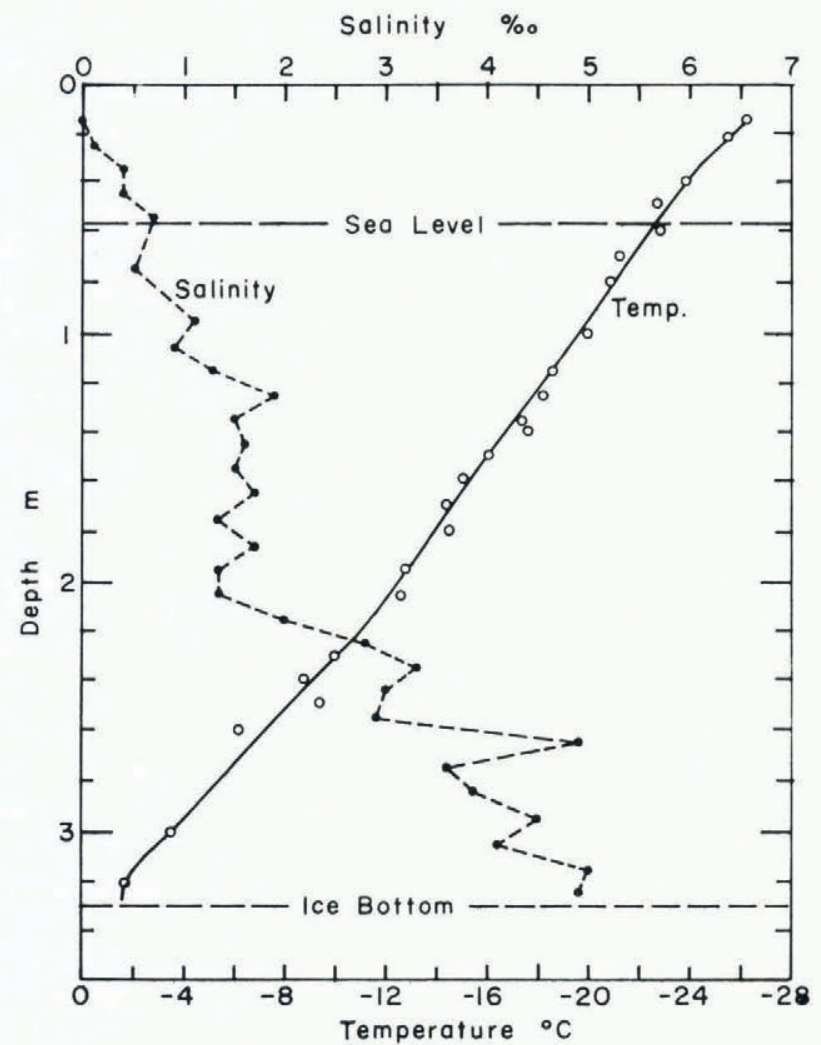

Fig. 2. Typical hummock salinity profile (profile $S_{I}$ ) and temperature profile. 


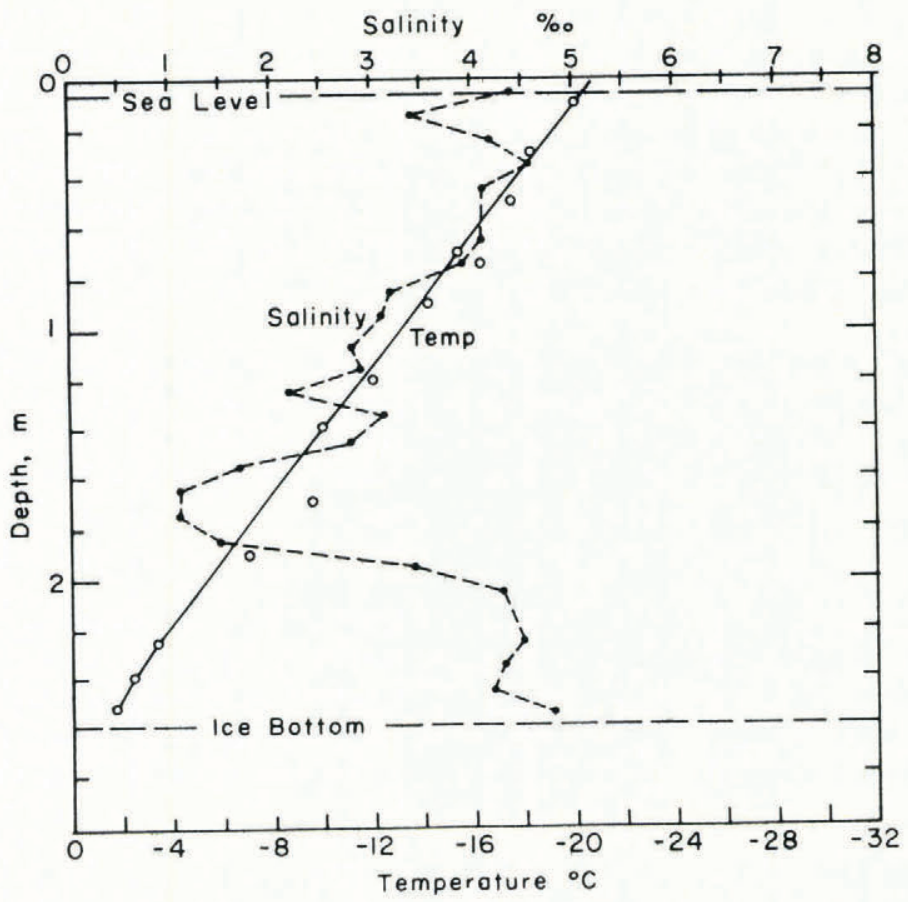

Fig. 3. Depression salinity profile $S_{5} b$ and temperature profile.

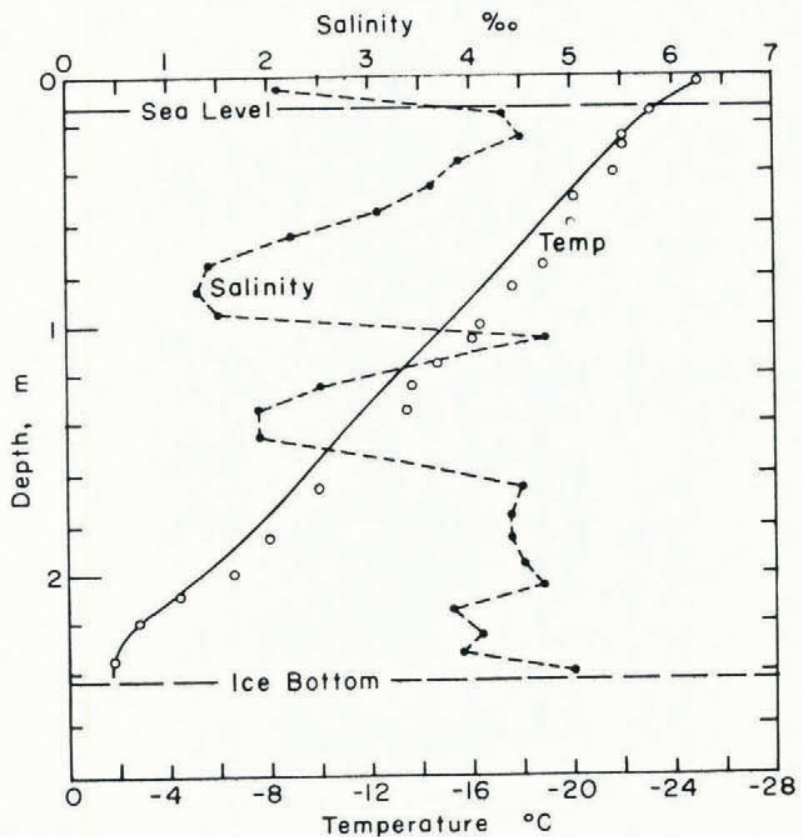

Fig. 4. Depression salinity profile $S_{2}$ and temperature profile. 
from the ice sheet. To compensate for this effect, only the maximum temperature values were considered when interpolating the temperature profiles shown in Figures 2, 3 and 4 . Figure 5 illustrates the ice topography, ice thickness, and relative position of some of the salinity cores.

For further comparison, average salinity profiles of both hummock and depression profiles were computed using the upper ice surface as a reference. Short periodic fluctuations were removed from individual profiles before averaging by calculating three-point (equally weighted) running means. The resulting curves are shown in Figure 6. Curve A is the average hummock profile based on seven cores, and curve B is the average depression profile based on ten cores. Curve $\mathrm{C}$ is the average multi-year sea-ice salinity profile determined by Schwarzacher (1959). The lower portions of the curves are the least reliable, because the profiles were not all of equal length. Curve B is not truly representative, in that the irregular salinity

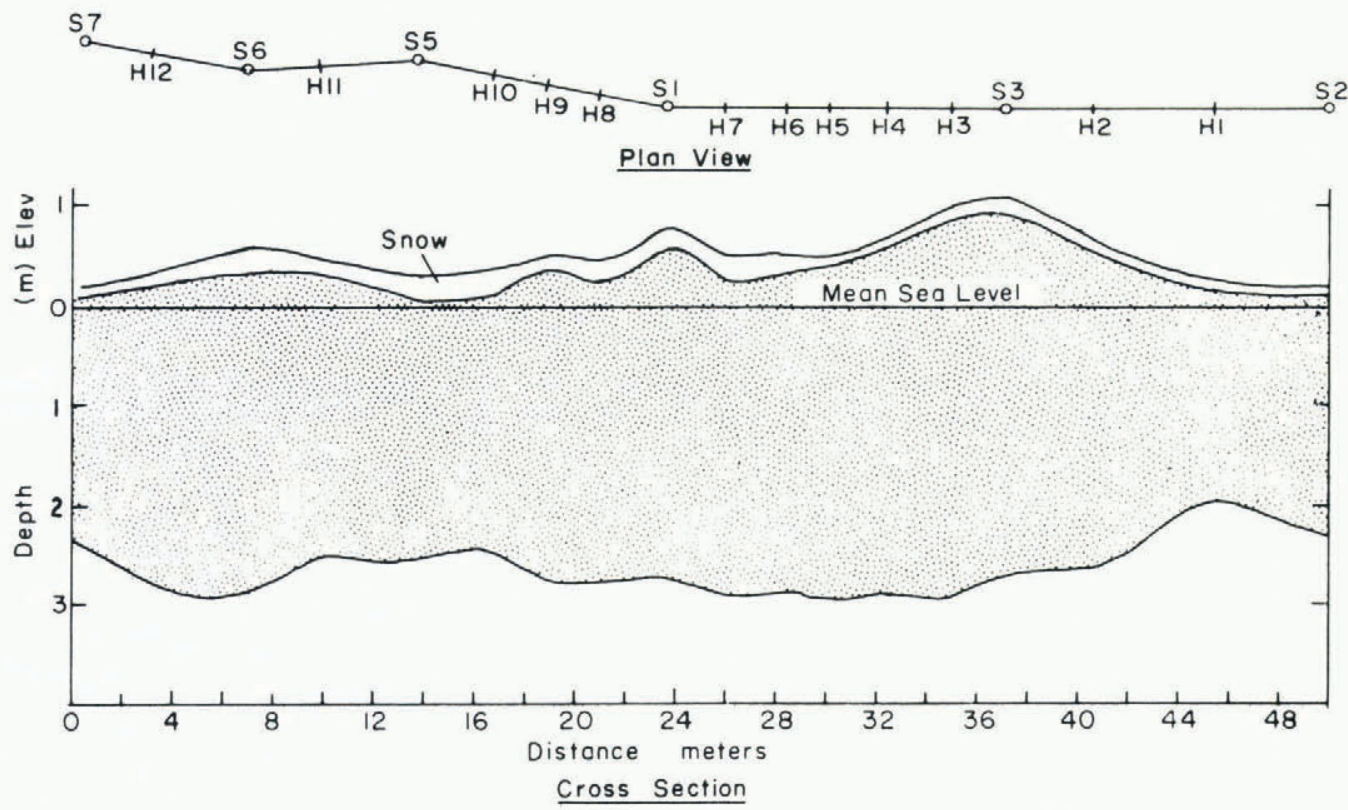

Fig. 5. Cross-section $A-A^{\prime}$ of Figure I illustrating ice topography, thickness and relative position of some of the salinity cores. $\mathrm{S}_{\mathrm{I}}, \mathrm{S}_{2}, \mathrm{~S}_{3}$, etc., denote salinity core sites; and $\mathrm{HI}_{\mathrm{I}} \mathrm{H}_{2}, \mathrm{H}_{3}$, elc. denote drill holes for ice thickness determinations.

fluctuations typical of individual depression profiles have been removed by averaging all the profiles. However, it is clear that the average salinity of the depression profile $(3.9 \%$ is much greater than that of the hummock profile $(2.6 \%)$.

Once it was determined that these differences were consistent, a depression-hummockdepression section was sampled in detail. To study the variation in salinity, cores were taken at I $\mathrm{m}$ intervals. The results (Fig. 7) illustrate several features typical of hummock and depression profiles. The salt content is much lower in the upper portion of the hummock than in the adjacent depressions. The salinity of the ice beneath the depressions is both greater and more variable. Distinct distribution patterns are also evident. The salinity in the center of the ice is distributed irregularly, with isolated high and low salinity pockets; the top and bottom portions are stratified. The lower, more uniform portion of the ice is undoubtedly the growth of the previous winter. 


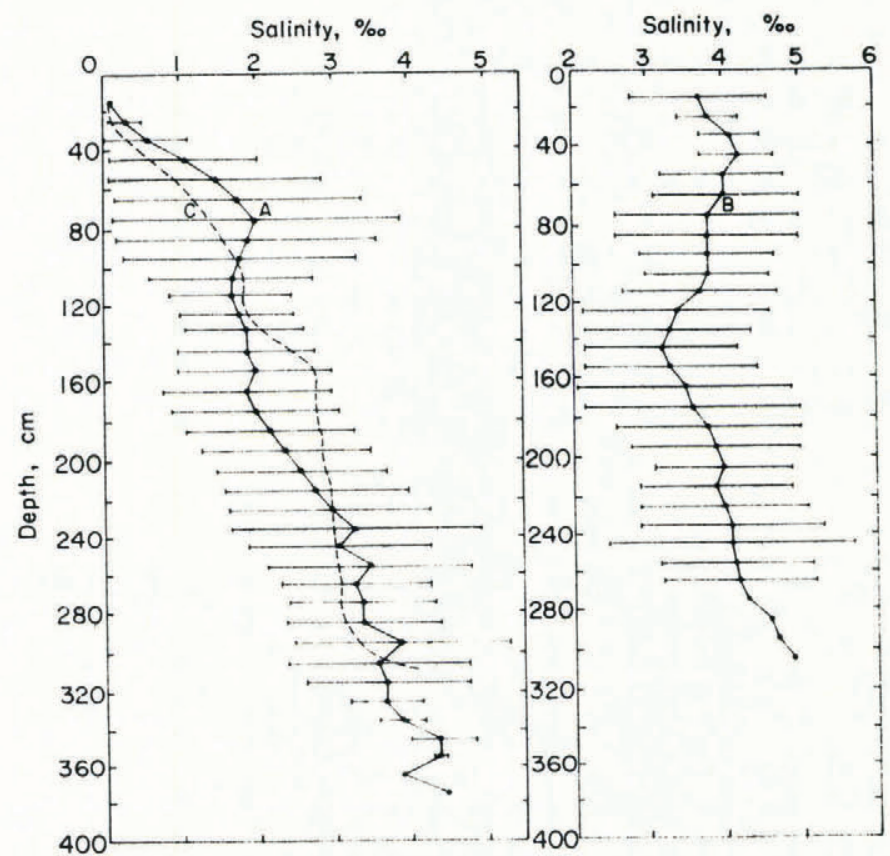
Fig. 6. Average salinity profiles. Curves $A$ and $B$ are the average hummock and depression salinity profiles, respectively. Curve $C$
is the multi-year ice average salinily profile determined by Schwarzacher (1959). The bars denote the standard deviation of the averaged values.

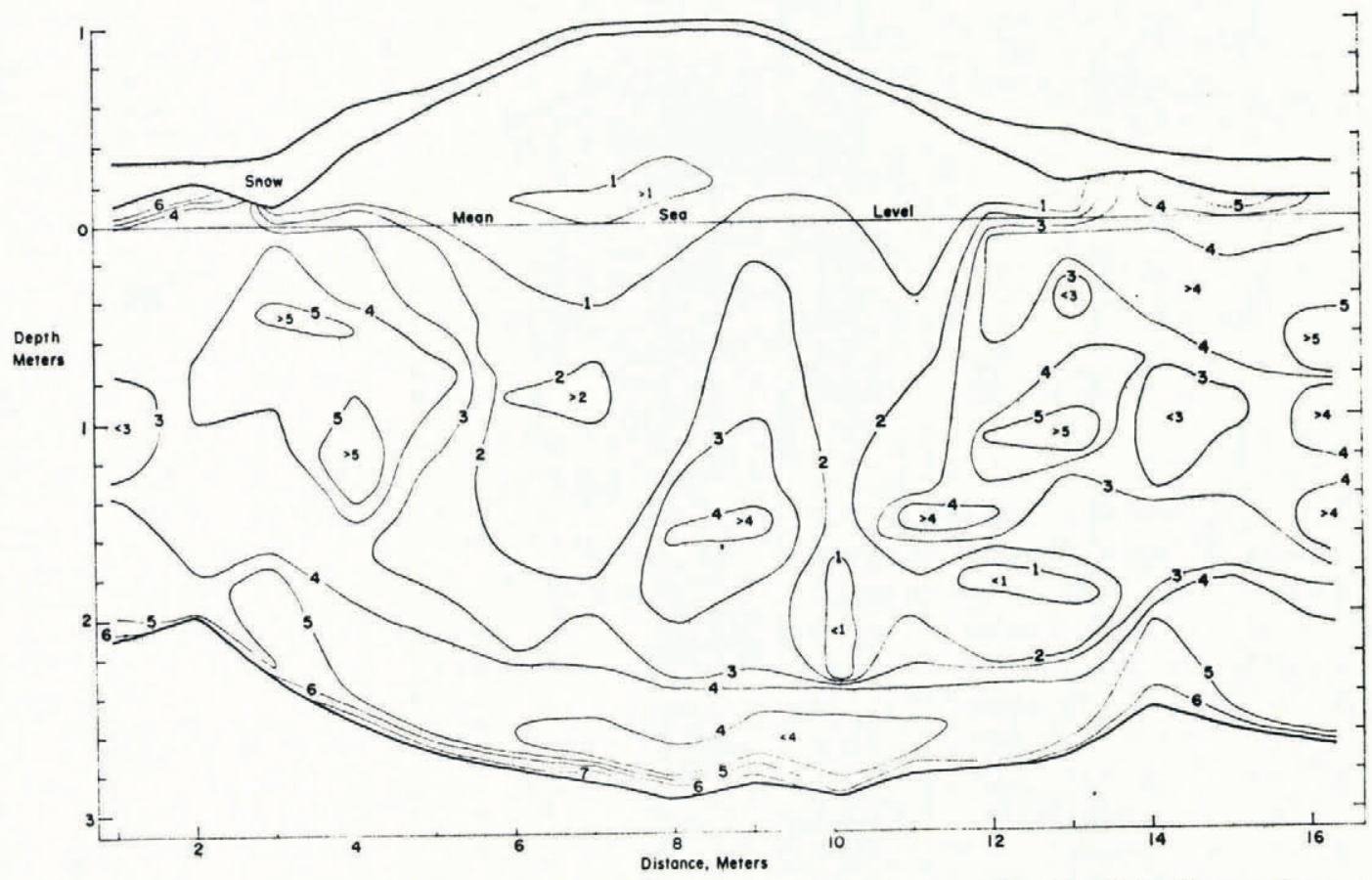

Fig. 7. Cross-section $B-B^{\prime}$ of Figure $I$ illustrating the variation of salinity with topography. Iso-salinity lines are drawn at ${ }_{1} \%$ intervals. 
A strong inverse correlation was found between the average salinity of the ice, as determined from its salinity profile, and the ice thickness at the profile location. Figure 8 plots the average salinity of the ice and the ice thickness as a function of position for profile $\mathbf{B}-\mathbf{B}^{\prime}$. As the thickness of the ice increases, the average salinity decreases. To examine this relation further, the AIDJEX data were supplemented with salinity observations from sea ice of varying thickness and age collected at other Arctic and sub-Arctic locations. The investigators, numbers of cores, and sampling locations and dates are summarized in Table I. In the analysis, the data were divided into two sets based on the condition of the ice at the time of sampling. Figure 9 contains the results from cores which were collected from cold ice during

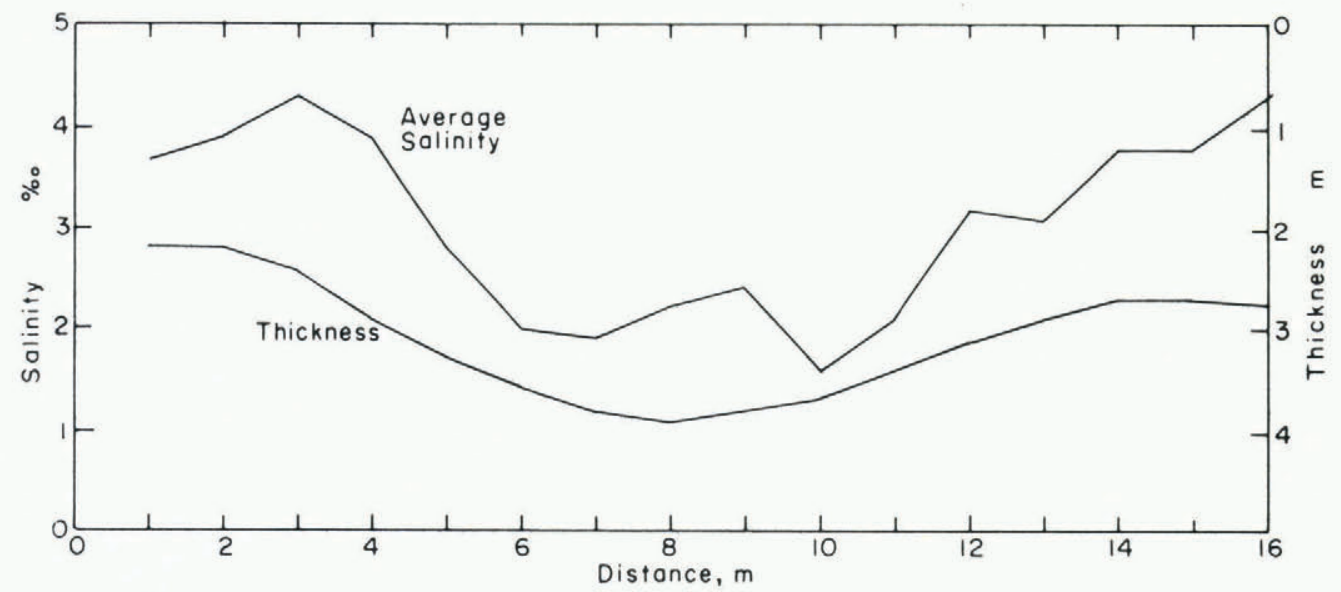

Fig. 8. Average salinity of the ice and the ice thickness plotted as a function of position for profile $B-B^{\prime}$ of Figure $I$.

TABle I. Data sources for AVerage SEA-ICE SAlinities (PERSonal communications)

\section{Location and ice type}

Cold ice $<0.4 \mathrm{~m}$

Hopedale, Labrador young young

Beaufort Sea

young

Cold ice $>0.4 \mathrm{~m}$

Hopedale, Labrador first-year

Bering Sea

first-year

Beaufort Sea

first-year

multiyear

multiyear

\section{Warm ice}

Hope dale, Labrador

$$
\text { frist year }
$$

Beaufort Sea

multiyear

Viscount Melville Sound

multiyear

$$
\begin{gathered}
\text { Thickness } \\
\text { m }
\end{gathered}
$$

Observation

period

No. of

cores Source

$0.08-0.40$

$0.22-0.4^{\circ}$

$0.08-0.40$

$0.68-0.9^{2}$

I.22-1.30

I.02-1. 48

I. $85-4.00$

2.10- 3.90

$1.03-1.18$
$2.64-3.60$
$0.88-3.88$
December-January I 955

October 1969

April 1972

January-March 1956

February-March 1970

April ${ }_{1969}$

March 1971

March-April 1972

March-May ${ }^{1956}$

June-August 1958

September-October 1969
25

I 4

24

Weeks and Lee

DenHartog

Cox

I5 Weeks and Lee

9 Kovacs and Kalafut

4 Kovacs

3 Kovacs and others

30 Cox

14 Weeks and Lee

9 Assur

I DenHartog 


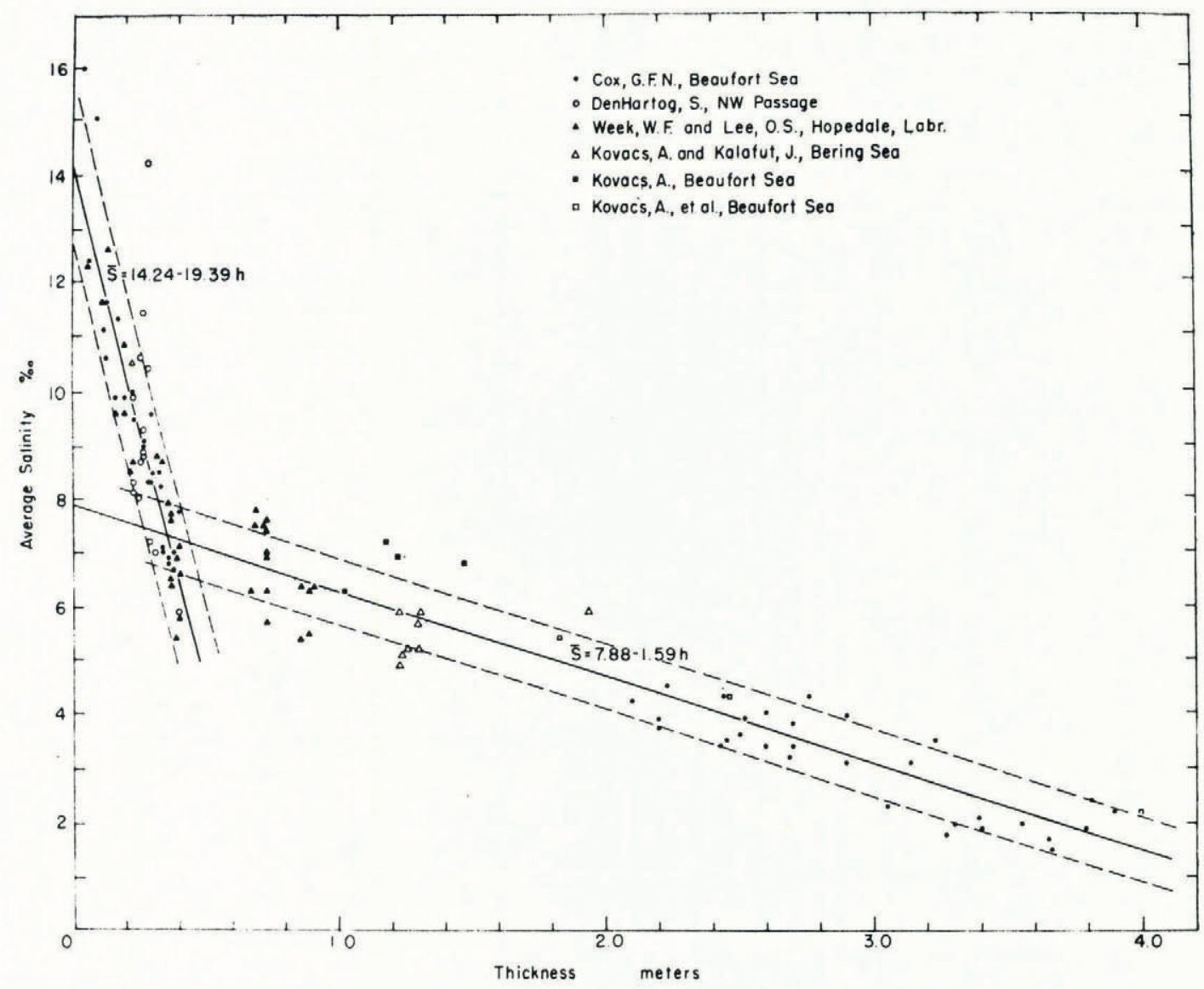

Fig. 9. Average salinity of sea ice as a function of ice thickness for cold sea ice sampled during the growth season. The standard error of the estimale is $1.5 \%$ for thin ice and $0.6 \%$ for thick ice.

the ice growth season. Figure io contains salinity samples taken only from warm, deteriorated ice during the melt season. In the cold ice (Fig. 9), there is a pronounced decrease in the mean ice salinity associated with an increase in the ice thickness, and a sharp break occurs in the curve at approximately $0.4 \mathrm{~m}$. The relationship between $\bar{S}$ (the average salinity of the ice in $\%$ ) and $h$ (the ice thickness in meters) can be well represented by two linear regression lines of $\bar{S}$ upon $h$ :

$$
\begin{array}{ll}
\bar{S}=14.24-19.39 h, & h \leqslant 0.4 \mathrm{~m}, \\
\bar{S}=7.88-\mathrm{I} .59 h, & h>0.4 \mathrm{~m} .
\end{array}
$$

The correlation coefficients for these relations are -0.78 and -0.94 , respectively, significantly different from zero at the 0.005 level. Least-squares fits of the combined data by a polynomial and exponential curve were also made. However, because of the apparent sharp break in slope at $0.4 \mathrm{~m}$, significantly poorer fits were obtained.

The decrease in $\bar{S}$ with increasing $h$ as shown in Figure 9 is hardly surprising; in first-year ice similar trends have been documented by Malmgren (1927) and by Weeks and Lee (1958, I962). However, the observation that the values from a wide variety of field sites lie on the same curve with very little scatter was unexpected, particularly for multi-year ice. 


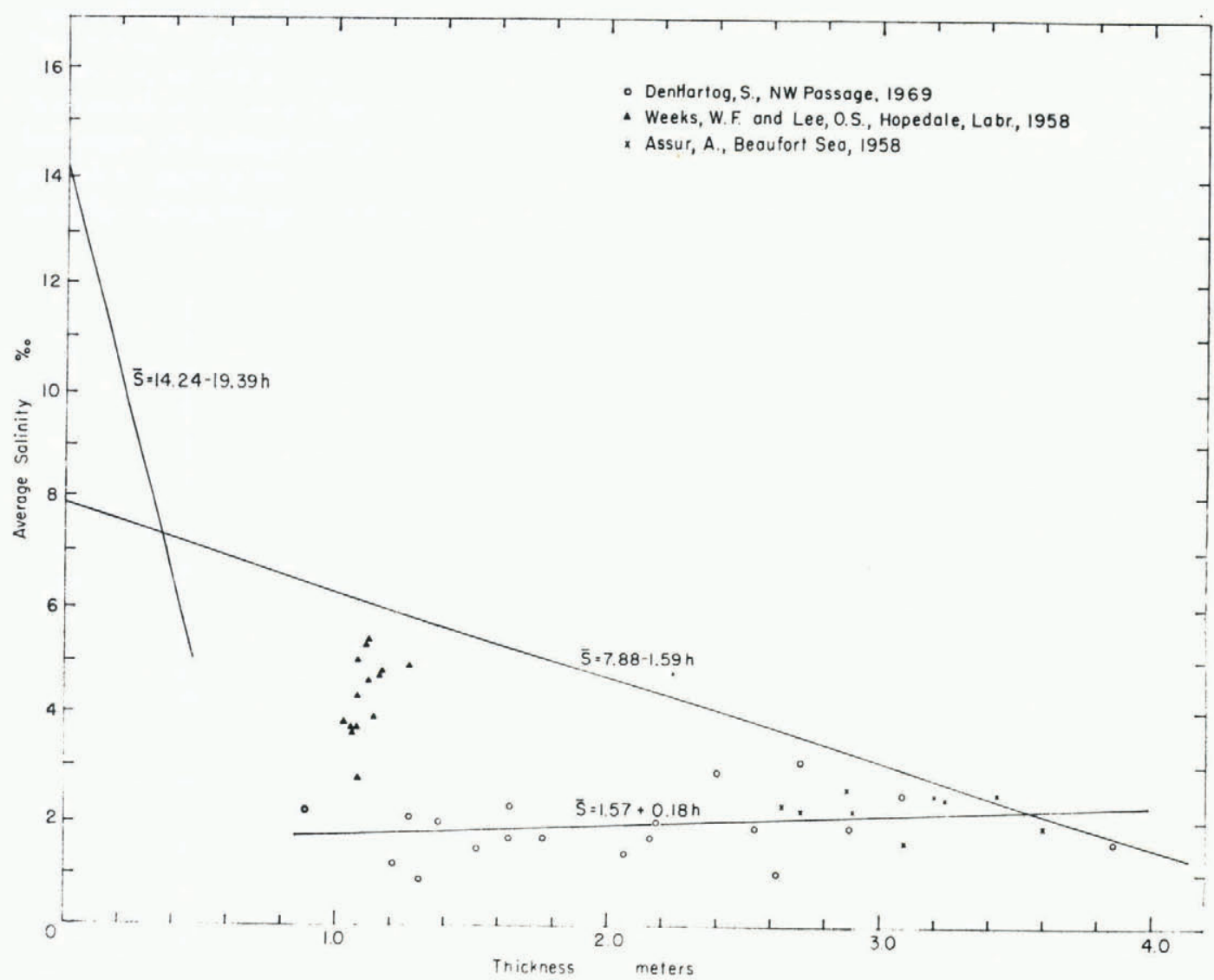

Fig. 10. Average salinity of sea ice as a function of ice thickness for warm sea ice sampled during or at the end of the melt season.

Figure ro shows a plot of $\bar{S}$ versus $h$ values obtained from sea ice that was nearly at melting temperature when sampled. Much of this ice showed signs of deterioration and contained large cavities and drainage tubes. Appreciable amounts of brine were probably lost during sampling. The data from Hopedale Labrador, were collected in first-year ice at the start of the melt season. The remainder of the data came from multi-year ice in Viscount Melville Sound and the Beaufort Sea. A linear regression line of $\bar{S}$ upon $h$ for these latter data gives

$$
\bar{S}=1.58+0.18 h
$$

with a correlation coefficient of +0.25 , which is not significantly different from zero at the o. ro level. The average salinity of the warm multi-year ice is clearly lower than the average observed for cold multi-year ice of a similar thickness.

\section{Discussion}

The low salt content (less than $1 \%$ ) of the upper portions of the hummocks is probably due primarily to brine drainage by flushing. Flushing resembles gravity drainage in that the brine moves through interconnected tubes and cavities. The force to overcome capillary retention is the hydrostatic head which is produced when snow or ice melts on the surface. A hydrostatic head limits flushing to periods of melt and to locations in which the ice above the 
freeboard is permeable (Untersteiner, 1967 ). If such a process is responsible for brine drainage, a strong relationship should be evident between the average salinity of the upper portion of the ice and the freeboard height. Most of the salinity profiles did show a decrease in salinity above sea-level (Figs. 2 and 4), and those that did not (Fig. 3) had a very low freeboard. Figure I I shows the average salinity of the upper meter of the ice plotted against the freeboard height. As the freeboard height increases, the average salinity of the upper portion of the ice decreases. The correlation coefficient for the data is -0.88 , which is significantly different from zero at the 0.005 level.

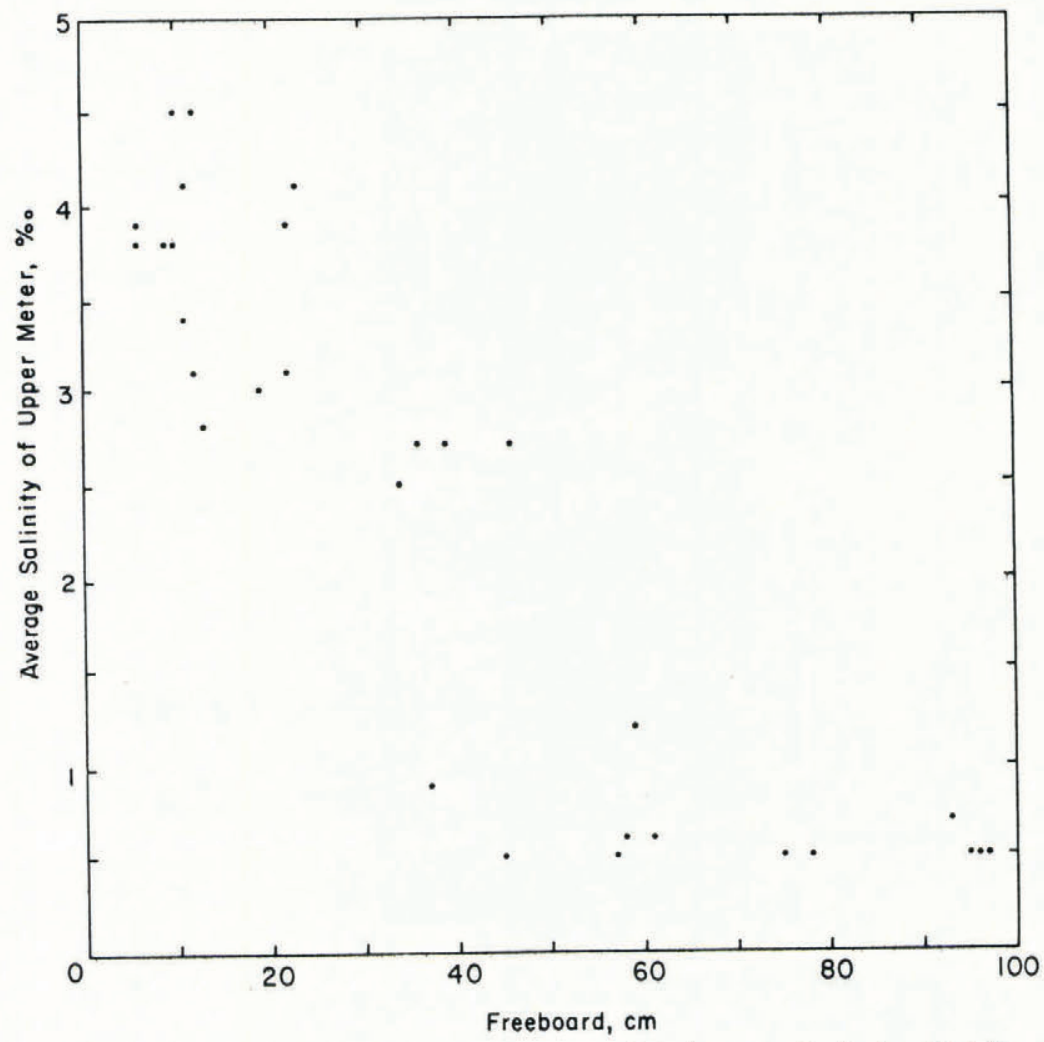

Fig. II. Plot of average salinity of the upper meter of the ice versus the freeboard height.

Since the growth history of the ice sheet is unknown, the characteristics of the depression salinity profiles cannot be readily explained. The high average salinity and crude $C$ shape of the depression profiles suggest that the ice beneath the depressions could be first-year. It is not uncommon to find first-year ice in excess of $2 \mathrm{~m}$. For instance, Langleben (1970) found smooth first-year ice $2.4 \mathrm{~m}$ thick in Tanquary Fiord, Ellesmere Island. The average salinity of this ice was about $4 \%$, which corresponds to the mean salinity of the average depression profile. Thus, the depressions may be areas within the multi-year floe that melted through during the previous summer and then refroze in the fall. The ice in such a frozen melt hole could conceivably exhibit the characteristics of the depression salinity profiles.

However, we doubt that these depressions were once melt holes. Not only is a melt hole a much rarer feature than a melt pond, but if all the depressions had indeed perforated the floe, it probably would not have survived the summer. A visit to the camp in October 1972 showed that only surface ponds had formed in the summer even though the floe was farther 
south than it had been in the summer of 1971 . We therefore believe that the differences we have observed between multi-year salinity profiles are related to surface melt pond formation and not to perforation.

The principal brine drainage mechanisms in sea ice are brine expulsion, gravity drainage, and flushing (Untersteiner, I967; Lake and Lewis, 1970). In Figure 9 it is possible that the change in slope of the mean salinity versus the ice thickness curve at $0.4 \mathrm{~m}$ is a result of a change in the dominant brine drainage mechanism from brine expulsion to gravity drainage. Recent experimental work on $\mathrm{NaCl}$ ice by the present authors* has shown that a pronounced decrease in the brine drainage rate occurs at an ice thickness of approximately $0.4 \mathrm{~m}$. However, more salinity data would probably show that the change in slope is continuous as opposed to the break in slope suggested by Figure 9 .

It is also interesting to speculate on the reason for the difference between the average salinity of the cold ice sampled during the growth season (Fig. 9) and that of the warm ice sampled during the melt season (Fig. I0). Not only does the warm multi-year ice have a lower mean salinity $(2.0 \%$, as compared to $3.0 \%$ ), it also shows a very slight increase in mean salinity with increasing ice thickness. This contrasts to a pronounced decrease in mean salinity over a similar range of ice thickness ( $1.0 \mathrm{~m}<h<4.0 \mathrm{~m}$ ) for cold ice. It is concluded that an annual cyclic variation of the mean salinity exists for multi-year sea ice. At the end of the melt season, after a period of ice deterioration and considerable brine drainage, the mean salinity reaches a minimum; and at the end of the growth season, after a period of bottom accretion and the refreezing of brine drainage cavities, the mean salinity reaches a maximum. The extent of the variations would be a function of the ice thickness. For example, the thinner the multi-year ice is at the end of the summer, the thicker the growth increment will be the following winter. Since the new ice will be more saline than the ice surviving the melt season, as shown quite clearly in Figure 7 , the average salinity will increase.

\section{Conclusions}

The salinity distribution in multi-year sea ice is dependent on the ice topography and cannot be represented by a single profile. Distinct differences were found between hummock profiles and depression profiles. If additional observations verify that the depression salinity profiles we observed are typical of areas beneath depressions, models which assume a single salinity distribution for multi-year sea ice will have to be modified. This is particularly true inasmuch as the average salinity profile determined by Schwarzacher appears to represent only the hummocks.

The general relation between ice thickness and mean salinity can serve as a check for numerical models that predict the time dependence of sea-ice salinity profiles as a function of both salt entrapment and brine drainage. The relation should be useful in working out correction factors in certain remote-sensing applications in which the signature of the ice depends upon the mean brine volume. It should be helpful in developing relations between the large-scale rheological response of an ice sheet and some measure of the mechanical properties of the ice being deformed. However, before any definitive conclusions can be made regarding the salinity distribution in multi-year sea ice, a much greater quantity of salinity data must be obtained, particularly from ice whose growth history is at least partially known. It will be easy to collect such data during the main AIDJEX experiment in $1975^{-76}$.

\section{Acknowledgements}

We would like to thank S. Ackley, W. D. Hibler, III, A. Kovacs and R. O. Ramseier for their assistance during the field work. Dr Hibler also advised us on certain data-handling

* A study of brine drainage in sodium chloride ice. Paper in preparation for publication. 
procedures. In addition, A. Assur, A. Kovacs and S. DenHartog made available a large number of unpublished salinity profiles.

This research was performed on a grant from the Office of Polar Programs of the National Science Foundation to the Cold Regions Research and Engineering Laboratory. It clearly would have been impossible without the enthusiastic support of $N$. Untersteiner and the staff of the AIDJEX project office.

MS. received II June 1973 and in revised form II September 1973

\section{REFERENCES}

Assur, A. 1967. Flexural and other properties of sea ice sheets. (In Oura, H., ed. Physics of snow and ice: international conference on low temperature science. . . 1966. . . Proceedings, Vol. I, Pt. I. [Sapporo], Institute of Low Temperature Science, Hokkaido University, p. 557-67.)

Lake, R. A., and Lewis, E. L. r970. Salt rejection by sea ice during growth. Journal of Geophysical Research,

Vol. 75, No. 3, p. 583-97.
Langleben, M. P. 1970. Reflection of sound at the water-ice interface. Journal of Geophysical Research, Vol. 75,

No. 27, p. 5243-46.
Malmgren, F. 1927. On the properties of sea ice. The Norwegian North Polar Expedition with the "Maud", $1918-1925$. Scientific results, Vol. I, No. 5 .

Maykut, G. A., and Untersteiner, N. 1971. Some results from a time-dependent thermodynamic model of sea ice. Journal of Geophysical Research, Vol. 76, No. 6, p. 1550-75.

Schwarzacher, W. 1959. Pack-ice studies in the Arctic Ocean. Journal of Geophysical Research, Vol. 64, No. 12, p. $2357-67$.

Untersteiner, N. 1967. Natural desalination and equilibrium salinity profile of old sea ice. (In Oura, H., ed. Physics of snow and ice: international conference on low temperature science. . . . 1966. . . Proceedings, Vol. I, Pt. I. [Sapporo], Institute of Low Temperature Science, Hokkaido University, p. 569-77.)

Weeks, W. F., and Assur, A. I967. The mechanical properties of sea ice. U.S. Cold Regions Research and Engineering Laboratory. Cold regions science and engineering. Hanover, N.H., Pt. II, Sect. C3.

Weeks, W. F., and Lee, O. S. I $95^{8}$. Observations on the physical properties of sea ice at Hopedale, Labrador.

Arctic, Vol. I 1 , No. 3, p. 134-55.
Weeks, W. F., and Lee, O. S. 1962 . The salinity distribution in young sea ice. Arctic, Vol. 15, No. 2, p. $92-108$. 